\title{
El anarquismo en Tucumán: expresiones de protesta y rituales obreros, 1900-1912
}

\author{
Anarchism in Tucuman: expressions of protest and workers' rituals, 1900-
} 1912

\section{Resumen}

El objetivo de este trabajo consiste en analizar las primeras expresiones anarquistas del asociacionismo laboral tucumano al despuntar el siglo XX, campo de análisis fértil en la historiografía provincial que no investigó esta temática para el periodo y el espacio elegido. Planteado desde un enfoque de historia social, el artículo explora las expresiones de protesta y los rituales obreros del anarquismo en Tucumán entre 1900 y 1912. Una de las principales hipótesis que plantea este estudio se refiere a la debilidad de las expresiones del anarquismo en Tucumán durante el periodo estudiado y a la interacción de sus militantes con trabajadores de otras tendencias de izquierda en el mundo del trabajo, como los socialistas, con quienes convivían -no exentos de tensiones y conflictos- en espacios obreros. Otro supuesto que subyace en esta investigación propone que si esta convivencia partidaria e ideológica concitó la crítica de algunos órganos de expresión libertarios, al mismo tiempo favoreció el respaldo de periódicos provinciales comerciales que no cuestionaron sus manifestaciones de protesta. Finalmente, el artículo sugiere que tanto en la prensa obrera como en los discursos de líderes anarquistas, socialistas y sindicalistas circuló un tópico recurrente de la época, la crítica a los trabajadores del Norte argentino, definidos como sujetos viciosos y poco instruidos para la militancia obrera.

Palabras clave: huelga de panaderos, dependientes de comercio, líderes obreros, $1^{\circ} \mathrm{de}$ mayo.

\begin{abstract}
The aim of this paper is to analyze the first anarchist expressions of workers' associations in Tucuman at the beginnings of the twentieth century, fertile field analysis in the historiography of the province which did not investigate this subject for the time span and the place chosen. Raised from the perspective of social history, the article explores the expressions of protest and workers' rituals of anarchism in Tucuman between 1900 and 1912. One of the main hypotheses raised by this study relates to the weakness of the expressions of anarchism in Tucuman during the period studied and the interaction of its members with other workers with left tendencies in the world of work, like the Socialists, with whom they lived-not without tensions and conflicts- in the same workers' space. Another assumption underlying this research suggests that if this partisan and ideological coexistence attracted criticism from some libertarians' bodies of expression, at the same time, it favored the support of
\end{abstract}

\footnotetext{
* Argentina, Doctora en Historia (El Colegio de México). Investigadora Adjunta del Consejo Nacional de Investigaciones Científicas y Técnicas (CONICET) y Docente de la Universidad Nacional de Tucumán (UNT). E-mail: vteitel@yahoo.com
}

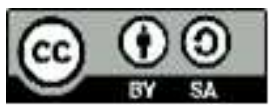


commercial provincial newspapers that did not question their protests. Finally, the article suggests that both the working press as well as the leading anarchists' speeches of socialists and trade unionists circulated a recurring topic of the time, criticism of the workers in the North of Argentine, who were defined as vicious and uneducated subject for worker's militancy.

Keywords: bakers' strike, shop runners' claims, labor leaders, May 1

\section{Introducción}

El objetivo de este trabajo consiste en analizar las primeras expresiones anarquistas del asociacionismo laboral tucumano al despuntar el siglo $\mathrm{XX}$, campo de análisis fértil en la historiografía provincial que no investigó esta temática para el periodo y el espacio elegido. Con lo cual, este estudio podría contribuir al avance del conocimiento de un terreno de estudio inexplorado referido al mundo del trabajo, los trabajadores y las izquierdas en Tucumán. ¿Qué consignas movilizaron a los anarquistas en Tucumán?, ¿quiénes fueron sus militantes y dirigentes? y ¿cuáles fueron sus medios y espacios de actuación? son parte de los interrogantes que guiaron esta investigación.

Para responder algunas de estas preguntas elaboramos el siguiente artículo planteado desde un enfoque de historia social --abierto, a su vez, a los aportes de la nueva historia política-- y basado principalmente en una metodología cualitativa explora las expresiones de protesta y los rituales obreros del anarquismo en Tucumán entre 1900 y 1912. La elección del recorte temporal no es caprichosa. Al despuntar el 900, se desarrolló la huelga de obreros panaderos, uno de los conflictos más sonados que tuvo lugar en San Miguel de Tucumán, capital y centro comercial y administrativo de Tucumán. Dicha protesta involucró a militantes del anarquismo y concitó la atención de la prensa que presentó miradas disímiles con respecto al comportamiento y resultado del movimiento huelguístico.

El estudio concluye hacia 1912, fecha en la cual se desarrolló otra significativa protesta en la capital tucumana, la protagonizada por dependientes de comercio que se identificaban con el movimiento libertario. Las narraciones de los diarios sobre la demanda que involucró actos violentos y atrajo la atención de la policía posibilitan reflexionar sobre las miradas en torno al anarquismo que circulaban en el ambiente. Asimismo, este conflicto sirvió para conocer algunos aspectos hasta ahora inexplorados en torno al accionar de líderes anarquistas que sobresalieron en el medio tucumano y sobre los cuales tratamos de reconstruir facetas de su trayectoria.

Otro vértice central del trabajo consiste en el examen de las veladas y publicaciones anarquistas que servían para transmitir las consignas libertarias tendientes a fomentar la transformación social hacia una sociedad más justa, libre e igualitaria, al tiempo que buscaban propiciar instancias de sociabilidad, educación y cultura entre los trabajadores. Dentro del repertorio de iniciativas sociales y culturales se destacaban las manifestaciones organizadas para evocar el Primero de Mayo. En esa dirección, haremos especial hincapié en el examen de los significados atribuidos por los anarquistas a esta efeméride central del 
calendario obrero y procuraremos establecer un contrapunto con las consideraciones del socialismo, principal impulsor de este ritual obrero.

Las problemáticas planteadas en el trabajo se vinculan con debates actuales de la disciplina en Argentina, en particular, los aspectos abordados en estas páginas recogen preocupaciones formuladas para ciudades como Buenos Aires, capital y centro neurálgico de la vida política y social argentina. Para dicho ámbito, se estudiaron las manifestaciones de asociación, protesta, sociabilidad, cultura y política de los trabajadores, temáticas que alentaron un amplio y valioso conjunto de investigaciones. ${ }^{1}$ En ese marco, podemos situar el análisis de las luchas obreras encabezadas por el socialismo, el anarquismo, el sindicalismo y el comunismo. Asimismo, el examen de los procesos de construcción de rituales obreros como el Primero de Mayo, su desarrollo, transformación y significados en pugna fueron objeto de importantes aportes. ${ }^{2}$

No obstante la importancia de estos temas, en Tucumán la magnitud que adquirió la agroindustria azucarera alentó el surgimiento de numerosas e insoslayables contribuciones dirigidas a examinar la vida de los distintos agentes involucrados en la producción y recolección de la caña de azúcar (como cañeros, empresarios azucareros, peones y

\footnotetext{
${ }^{1}$ Referentes centrales para nuestra investigación fueron los trabajos de Ricardo Falcón, Los orígenes del movimiento obrero (1857-1899), Buenos Aires, Centro Editor de América Latina, 1984, El mundo del trabajo urbano (1890-1914) y La Barcelona Argentina, Rosario, Laborde editor, 2005; Juan Suriano, Anarquistas. Cultura y política libertaria en Buenos Aires, 1890-1910, Buenos Aires, Manantial, 2001,Mirta Zaida Lobato, La prensa obrera, Buenos Aires, Edhasa, Temas de la Argentina, 2009, pp.175 y Mirta Zaida Lobato y Silvana Alejandra Palermo, "Del trabajo a las calles: dignidad, respeto y derechos para los y las trabajadoras", Mirta Zaida Lobato (Editora), Buenos Aires. Manifestaciones, fiestas y rituales en el siglo XX, Buenos Aires, Biblos, 2011, pp. 45-74 y Enrique Mases, "El tiempo libre de los trabajadores en la norpatagonia. De la cultura política, las prácticas recreativas y deportivas al disciplinamiento social 19001945", Quinto Sol n 9-10, Instituto de Estudios Socio-Históricos-Facultad de Ciencias Humanas, Universidad Nacional de La Pampa, 2005-2006, pp. 73-97. Para otros periodos, Hernán Camarero, A la conquista de la clase obrera. Los comunistas y el mundo del trabajo en la Argentina, 1920-1935, Buenos Aires, Siglo XXI, 2007 constituye un análisis valioso sobre las experiencias asociativas y culturales lideradas por los comunistas en el mundo del trabajo argentino entre 1920 y 1935.

${ }^{2}$ Un sugerente trabajo dirigido a rastrear las luchas en el interior del movimiento obrero y delimitar las concepciones socialistas y anarquistas en torno al Primero de Mayo es el de Lucas Poy, "Socialismo y anarquismo en los orígenes del Primero de Mayo en Argentina (1890-1895), Trabajadores, Año 1, $\mathrm{N}^{\circ} 2$, Segundo Semestre, 2011, pp. 27-57. Para un periodo comprendido entre 1890 y 1950 contamos con el trabajo pionero de Viguera, Aníbal, "El primero de mayo en Buenos Aires, 1890-1950: evolución y usos de una tradición", Boletín del Instituto de Historia Argentina y Americana "Dr. E. Ravignani", Tercera Serie, n. ${ }^{\circ} 3$, 1991, pp. 57-60. Otros valiosos análisis sobre el tema, en especial un examen de los recorridos, símbolos y sentidos del Primero de Mayo desde sus orígenes en Argentina hasta el peronismo en Lobato, 2009 y Lobato y Palermo, op. cit. Referentes indispensables para este trabajo son, a su vez, los análisis de Juan Suriano sobre las manifestaciones anarquistas del $1^{\circ}$ de mayo (Suriano, 2001, op.cit.). Un recorte temporal más amplio y aportes recientes en Suriano, Juan y Anapios, Luciana, "Anarquistas en las calles de Buenos Aires (18901930)", en Lobato, 2011, op. cit., 84 -85. Para otras latitudes latinoamericanas como Brasil, me sirvió, especialmente, el artículo de Bilhão, Isabel, "Dia de festa, dia de luto ou feriado nacional? As diferentes concepções do Primero de Maio no Brasil ao longo dos anos 1929", Hib, Revista de Hitoria Iberoamericana, Vol. 6, $\mathrm{n}^{\mathrm{o}}$ 1, 2013, pp. 29-52. Indispensable para enmarcar los orígenes y transformaciones del Primero de Mayo a nivel mundial fue el trabajo de Eric Hobsbawm, "El nacimiento de una fiesta: El Primero de Mayo, Eric Hobsbawm, Gente poco corriente. Resistencia, rebelión y jazz, Buenos Aires, Crítica, 2013, 132-147.
} 
jornaleros del azúcar). ${ }^{3}$ Con lo cual, los trabajadores abocados a oficios ajenos al ámbito de los ingenios y establecimientos azucareros no recibieron la suficiente atención por parte de la historiografía provincial. Para subsanar este vacío este artículo se propone avanzar en el análisis de las expresiones del asociacionismo obrero en Tucumán, con una explicación sobre las prácticas y los discursos de trabajadores de oficio y dependientes de los distintos establecimientos de servicios ubicados en la ciudad de San Miguel de Tucumán y que militaron en asociaciones obreras de naturaleza diversa.

El trabajo se basa en un conjunto de fuentes, tales como los artículos contenidos en la prensa provincial, en especial las noticias publicadas en El Orden, principal diario de Tucumán durante la época estudiada. ${ }^{4}$ Asimismo, nos apoyamos en la información obtenida en los semanarios y periódicos socialistas, anarquistas y sindicalistas publicados en Buenos Aires. En esa dirección, revisamos las notas sobre el movimiento obrero tucumano difundidas en La Vanguardia, La Protesta y La Acción Socialista. ${ }^{5}$ Para abordar las implicancias de la huelga de los panaderos resultaron fundamentales diarios obreros y gremiales como El Obrero y El Obrero Panadero, ${ }^{6}$ mientras el reclamo de los dependientes de comercio se exploró con los datos obtenidos del ya mencionado El Orden, complementados con las narraciones difundidas en La Gaceta, fundada en 1912, año en el cual tuvo lugar la protesta mencionada. Por su parte, las consideraciones en torno al Primero de Mayo fueron examinadas con el apoyo de un documento invaluable para el estudio del anarquismo en el periodo de formación del movimiento obrero en Tucumán: la

\footnotetext{
${ }^{3}$ En especial, Campi, Daniel, Azúcar y trabajo. Coacción y mercado laboral, Tucumán, 1856-1896, tesis doctoral (inédita), Universidad Complutense de Madrid, 2002 y Bravo, María Celia, Campesinos, azúcar y política. Cañeros, acción corporativa y vida política en Tucumán (1895-1930), Rosario, Prohistoria, 2008.

${ }^{4}$ Revisé el diario El Orden desde 1897 a 1917. Su consulta fue realizada principalmente en el Archivo Histórico de Tucumán (AHT). El Orden fue fundado en 1883 por Ernesto Columbres y fue el diario de más larga vida en Tucumán; incluso para 1948 seguía existiendo, aunque ya muy disminuido (Manuel, García Soriano, "El periodismo tucumano: 1817-1900. Ensayo de investigación sobre un aspecto de la cultura de Tucumán durante el siglo XIX", Cuadernos de Humanitas, 38, Tucumán, Universidad Nacional de Tucumán, Facultad de Filosofía y Letras, 1972, 30-39). Creado en 1883, en plena época roquista, El Orden transitó desde el apoyo al gobierno provincial de Lucas Córdoba y a su partido oficial "Unión Provincial" que respaldaba al gobierno del presidente Roca a su transformación hacia 1902-1903 en un órgano de expresión opositor, portavoz del bloque político integrado por industriales azucareros adversos a la política de L. Córdoba, gobernador de Tucumán entre 1895 y 1898 y entre 1901 y 1904. Como portavoz de esta nueva corriente política, El Orden, recrudeció sus críticas al "luquismo" (denominación que hacía alusión directa a la figura del gobernador Lucas Córdoba), inscribiéndose abiertamente en el sector opositor al roquismo (María Celia, Bravo, "Liberales, socialistas e Iglesia frente a la situación de los trabajadores en Tucumán", Suriano, Juan, La cuestión social en la Argentina, 1870-1943, Editorial La Colmena, Buenos Aires, 2000, pp. 31-61).

${ }^{5}$ Consulté La Acción Socialista, La Vanguardia y La Protesta en el Centro de Estudios e Investigación sobre las Izquierdas (CeDiNCI), en Buenos Aires. Los años analizados fueron, aproximadamente, desde 1898 a 1910. La Vanguardia fue originalmente un semanario y luego se transformó en un diario, órgano oficial del partido Socialista en Argentina. Por su parte, La Protesta Humana (primero denominada La Protesta Humana), fue sin duda uno de los principales medios de expresión del anarquismo en el país. La Acción Socialista fue el periódico que representaba a la corriente sindicalista revolucionaria, una vez que ésta se separó del Partido Socialista.

${ }^{6}$ Quiero agradecer a Lucas Poy por compartir generosamente la digitalización de estas fuentes resguardadas en el en el Instituto Internacional de Historia Social (IIHS), situado en Ámsterdam (Países Bajos).
} 
revista Germinal, $^{7}$ que fue editada en el año 1908 como un número único por parte de la Federación Obrera Local Tucumana (FOLT), central de trabajadores adherida a la Federación Obrera Regional Argentina (FORA), de naturaleza anarquista. ${ }^{8}$ Se trata, sin lugar a dudas, de publicación sumamente valiosa, en tanto constituye una de las escasísimas fuentes sobre las prácticas anarquistas en Tucumán durante la época estudiada, incluso Germinal fue la primera publicación anarquista del norte argentino.

Una de las principales hipótesis que plantea este trabajo se refiere a la debilidad de las expresiones del anarquismo en Tucumán durante el periodo estudiado y a la interacción de sus militantes con trabajadores de otras tendencias de izquierda en el mundo del trabajo, como los socialistas, con quienes convivían no exentos de tensiones y conflictos-- en espacios obreros. Estrechamente relacionado con lo anterior, otro supuesto que subyace en este estudio propone que si esta convivencia partidaria e ideológica concitó la crítica de algunos órganos de expresión libertarios, al mismo tiempo favoreció el respaldo de periódicos provinciales comerciales que no cuestionaron sus manifestaciones de protesta. Finalmente, el artículo sugiere que tanto en la prensa obrera como en los discursos de líderes anarquistas, socialistas y sindicalistas circuló un tópico recurrente de la época, la crítica a los trabajadores del Norte argentino, definidos como sujetos viciosos y poco instruidos para la militancia obrera.

\section{Mundo del trabajo y conformación de un entramado asociativo en Tucumán}

Hacia mediados del siglo XIX y, particularmente, desde la década de 1880, el crecimiento económico basado fundamentalmente en la industrialización azucarera acompañó un significativo aumento de la población y avances en materia de desarrollo de la infraestructura urbana y las comunicaciones. Los guarismos de los censos nacionales reflejaron este crecimiento, tal como se evidenció en el número de habitantes de la provincia de Tucumán que pasó de 108.953 individuos contabilizados en 1869 a 215.742 registrados en 1895. La capital de la provincia, la ciudad de San Miguel de Tucumán, fue la urbe que mejor evidenció este crecimiento poblacional, al pasar de 17.438 habitantes en 1869 a 34.306 en 1895.

Paralelamente, la capital de la provincia fue testigo de numerosas transformaciones edilicias y el mejoramiento de los servicios públicos, cambios que sin embargo se limitaron al radio central de la ciudad, zona habitada mayoritariamente por los grupos acomodados. ${ }^{10}$

\footnotetext{
${ }^{7}$ Agradezco la generosidad de María Fernández de Ullivarri quien me facilitó este material localizado en el IIHS, de Ámsterdam.

${ }^{8}$ La Protesta, 19/10/1907.

${ }^{9}$ Al respecto, remitimos al estudio pionero de Santiago, Bilbao, “Anarquismo en el noroeste a principio del siglo XX: Germinal, publicación tucumana”, Estudios del Trabajo, N 28, 2004, 143-151.

${ }^{10}$ Breves Contribuciones del Instituto de Estudios Geográficos, Monografía I, Tucumán, Universidad Nacional de Tucumán, Facultad de Filosofía y Letras, 1988, Curia de Villeco, María Elena y Bolognini, Víctor Hugo, Inmigración en Tucumán, Tucumán, Universidad Nacional de Tucumán, Facultad de Filosofía y Letras, Instituto de Historia y Pensamiento Argentino, 1992, Saltor, Irene, "Aspectos de la Modernidad. Tucumán, 1880-1890", Revista de la Junta de Estudios Históricos de Tucumán, Año VIII, N 5, 1993, pp. 3361 y Fernández, María Estela, "Salud y condiciones de vida. Iniciativas estatales y privadas, Tucumán fines del siglo XIX y comienzos del XX”, Adriana Álvarez, Irene Molinari y Daniel Reynoso (editores), Historia
} 
En contraste, el grueso de la clase trabajadora vivía en viviendas sumamente precarias, carecía completamente de servicios públicos y estaba expuesta cotidianamente a situaciones de insalubridad, falta de higiene y hacinamiento habitacional. ${ }^{11}$ Asimismo, los trabajadores enfrentaban la dureza de los regímenes laborales caracterizados por prolongadas jornadas, malos tratos, jornales impagos e insuficiencia del salario así como el incumplimiento de las condiciones acordadas (referidas a horarios, salarios, etc.). Por supuesto, las situaciones variaban según los oficios y establecimientos laborales. En general los obreros y peones de los ingenios se encontraban entre los trabajadores más explotados y sujetos a las condiciones de trabajo más rígidas. ${ }^{12}$

En este universo laboral, heterogéneo y segmentado, ${ }^{13}$ se implementaron estrategias de organización de los trabajadores que, de forma similar a otros espacios argentinos y latinoamericanos, buscaron hacer frente a las contingencias y avatares de la vida mediante la formación de asociaciones de naturaleza diversa. Mayoritariamente, los trabajadores crearon mutuales establecidas con el propósito de prestar auxilio a sus miembros ante casos de enfermedad, accidentes y fallecimiento. Muchas de estas formaciones, además, contemplaron la ayuda mutua frente a situaciones de desempleo y organizaron numerosas actividades de sociabilidad y cultura. ${ }^{14}$

de enfermedades, salud y medicina en la Argentina de los siglos XIX y XX, Universidad Nacional de Mar del Plata, 2004.

${ }^{11}$ Moreno, Daniela y Chiarello, Analía, "La ciudad de papel. Los proyectos de avenida dentro del casco fundacional", en Perilli de Colombres Garmendia, Elena y Romero, Estela, La Generación del Centenario y su proyección en el noroeste argentino (1900-1950), Tucumán, Centro Cultural Alberto Rougés, 2006 y Paterlini de Koch, Olga, Pueblos Azucareros de Tucumán, Tucumán, Universidad Nacional de Tucumán, 1987.

${ }_{12}$ Para un estudio de las condiciones de vida de los trabajadores en Argentina, ver, por ejemplo, Suriano, Juan, "El largo camino hacia la ciudadanía social", Torrado, Susana (comp.), Población y bienestar en la Argentina del primero al segundo Centenario. Una historia social del siglo XX, 2007, 67-95. La situación de los trabajadores en Tucumán es examinada por Fernández, María Estela, "Las políticas de salud: el caso de los hospitales en Tucumán a fines del siglo XIX", X Jornadas Interescuelas/Departamentos de Historia, Rosario, 20 al 23 de septiembre, 2005 y Bravo, María Celia y Teitelbaum, Vanesa, "Socialistas y católicos disputando el mundo los trabajadores. Protesta, sociabilidad y política en Tucumán (1895-1910)", Entrepasados, Revista de Historia, Año XVIII, nº 35, Buenos Aires, 2009, 67-87.

${ }^{13} \mathrm{Al}$ respecto, Bravo y Teitelbaum, op. cit., 67-87.

${ }^{14}$ Contamos con una extensa y sugerente bibliografía el mutualismo en América Latina. Imposible mencionar todos los aportes sobre el tema en estas páginas. Únicamente, a modo de ejemplo, mencionaremos algunos de los trabajos que más nos sirvieron para nuestra investigación, tales como los Di Stefano, Roberto, Capítulo Uno/ 1776-1860, Luna, Elba y Cecconi, Elida, (Idea y coordinación), De las cofradías a las organizaciones de la sociedad civil". Historia de la iniciativa asociativa en Argentina, 1776-1990, Buenos Aires, Edilab Editora, 2002, 23-97 y Sabato, Hilda, Capítulo 2/1860-1920, Estado y sociedad civil, en Luna y Cecconi, 2002, op. cit, 99-167, para Argentina. Para otras latitudes de América Latina, como Chile, contamos con los de Grez Toso, Sergio, "La trayectoria histórica del mutualismo en Chile (1853-1990). Apuntes para su estudio", Mapocho, Revista de Humanidades y Ciencias Sociales, No 35, Primer Semestre de 1994, 293-315; para países europeos como Alemania y España, disponemos de los aportes de Kocka, Jürgen, "Los artesanos, los trabajadores y el Estado: hacia una historia social de los comienzos del movimiento obrero alemán," Historia Social, No 12, Invierno 1992, 101-11, Aizpuru, Mikel y Rivera, Antonio, Manual de historia social del trabajo, Madrid, Siglo XXI, 1994 y Larraza Micheltorena, María del Mar, "El asociacionismo obrero pamplonés (1900-1923)", Gerónimo de Uztariz, N 14/15, 1999, 55-104.

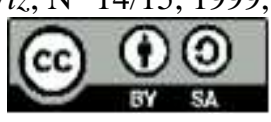


En un segundo momento, y al influjo de la propaganda socialista, anarquista y sindicalista, se crearon asociaciones gremiales y de resistencia con la consigna central de luchar por mejoras laborales, a través de instancias de protesta que contemplaban petitorios, movilizaciones y huelgas. ${ }^{15}$

De acuerdo al examen de las fuentes, podemos proponer que la mayoría de las protestas de los trabajadores se condensó en demandas relacionadas con el incremento salarial, la obtención de la jornada de 8 horas y la sanción del derecho al descanso dominical, reclamos básicos del movimiento obrero en la época. A su vez, los reclamos se canalizaron en gran medida a través del accionar de centros obreros que reunían en su interior a militantes de distintas tendencias políticas e ideológicas. En ese contexto, sobresalió la actuación del Centro Cosmopolita de Trabajadores, fundado en 1897 en la ciudad de San Miguel de Tucumán y, posteriormente, el Centro Socialista, establecido en 1905 y adherido al partido Socialista en Argentina.

El Centro Cosmopolita de trabajadores originalmente se había conformado como una asociación de "protección mutua" que perseguía la consigna de "uno para todos y todos para uno". No obstante, en la práctica, este ámbito funcionó como un centro político, cultural y de protesta que integrado mayoritariamente por trabajadores de oficio albergaba en su interior a representantes de distintas corrientes ideológicas, como el reformismo liberal y militantes de movimientos de izquierda en el mundo del trabajo, como el anarquismo y, el socialismo. Al despuntar el siglo XX, el Centro Cosmopolita se enmarcó más claramente en los lineamientos establecidos por las fuerzas obreras y se convirtió en el espacio de expresión del activismo libertario y socialista. ${ }^{16}$ Estas dos tendencias, el anarquismo y el socialismo, convivieron en este ámbito obrero e impulsaron protestas, conferencias, veladas literario-musicales y manifestaciones públicas. Sin embargo, las tensiones y enfrentamientos no estuvieron ausentes e impactaron en las prácticas organizadas por ambas fuerzas de izquierda. Un ejemplo de los problemas se manifestó a raíz de las conferencias desarrolladas en el Centro Cosmopolita y en donde al parecer los anarquistas acostumbraban ausentarse. Asimismo, las fricciones se revelaron especialmente por asuntos relacionados con el manejo de los fondos económicos. Tales disputas llevaron finalmente a la salida de los anarquistas del Centro Cosmopolita de Trabajadores y, posteriormente, a la disolución de este ámbito obrero a comienzos de 1905. También en la escisión de esta asociación pudieron haber desempeñado un papel clave los sucesos a nivel nacional, en particular es factible pensar que en las discusiones entre los socialistas y anarquistas del Centro Cosmopolita de Trabajadores de Tucumán alcanzaron un impacto los efectos de la primera gran división del partido Socialista en el país, expresada en la salida de los anarcosindicalistas de esta fuerza política.

En suma, anarquistas y socialistas convivieron --no exentos de tensiones y conflictos-- en el Centro Cosmopolita de Trabajadores y participaron en actividades sociales, culturales, gremiales entre finales del siglo XIX y comienzos del XX. Una muestra en ese sentido se reflejó en la solidaridad obrera expresada durante uno de los principales conflictos que tuvieron lugar en la ciudad de San Miguel de Tucumán: la huelga de

\footnotetext{
${ }^{15}$ Valiosas obras sobre el tema son Falcón, 1986, op. cit., y Falcón, 2005, op. cit., así como las de Mases, op. cit. y Suriano, 2001, op. cit.

${ }^{16}$ La Vanguardia, 11/12/1897, 18/06/1898, 5/1/1901 y 19/1/1901.
} 
panaderos desarrollada en los primeros años del 900. Los contornos que adquirió este conflicto serán analizados a continuación en el marco de un examen de las protestas anarquistas. Este estudio nos permitirá aproximarnos a las relaciones entre las distintas corrientes que integraron el movimiento obrero en Tucumán en su etapa formativa y develar el pasaje desde la convivencia entre socialistas y anarquistas en el Centro Cosmopolita y sus manifestaciones de respaldo mutuo --ejemplificadas con la huelga de panaderos-- hasta las mutuas descalificaciones aparecidas en las publicaciones obreras varios años después. De esta relación compleja entre las manifestaciones de izquierda en el mundo del trabajo, por cierto un rasgo que no fue privativo de Tucumán, es factible plantear algunas cuestiones, tales como la expresión aún incipiente del anarquismo en la provincia en esta etapa. Posteriormente, el anarquismo adquirió mayor presencia en Tucumán, en consonancia con la creación de los Talleres Ferroviarios, fundados en 1910 e inaugurados en 1912, en la ciudad de Tafí Viejo, localidad situada en el interior tucumano. Antes de ello, sin embargo, la debilidad de esta fuerza alentó posiblemente la interacción con otras expresiones asociativas de izquierda como el socialismo, movimiento que sin duda evidenció más poderío en este periodo inicial del asociacionismo obrero tucumano.

\section{Anarquismo y protesta}

A continuación, me ocuparé de las protestas que revelaron la participación de los militantes anarquistas, con el fin de avanzar en una de las facetas menos conocidas de la vida de los trabajadores en Tucumán en los umbrales del siglo XX. Sin ánimo de agotar el tema con estas páginas, revisaremos las luchas que evidenciaron el accionar de los grupos libertarios, sectores minoritaria y escasamente documentados pero absolutamente imprescindibles para arribar a un conocimiento más completo acerca del universo asociativo laboral tucumano.

Pero antes de comenzar el análisis propiamente dicho conviene delimitar algunas de las características del asociacionismo obrero tucumano en la época. En tal sentido, interesa subrayar la presencia de distintas expresiones al interior del movimiento obrero: el socialismo, el anarquismo --en un momento posterior se sumará sindicalismo y, de forma más tardía, el comunismo. Como ya se dijo, socialistas y anarquistas convivieron al interior de un mismo espacio obrero como el Centro Cosmopolita, aunque hacia 1905 los caminos se bifurcaron y ambas tradiciones de izquierda comenzaron itinerarios separados. A su vez, cada una de estas expresiones alimentó relaciones y formó parte de organizaciones de segundo grado. Tal fue el caso del socialismo que se vinculó con el partido Socialista en Argentina y formó parte de la Unión General de Trabajadores (UGT) liderada por los socialistas. Por su parte, los anarquistas crearon la FOLT que integró la FORA, dominada por el movimiento libertario.

\section{La huelga de panaderos en 1900}

Una de las protestas que se destacaron en el periodo temprano de formación del movimiento obrero en Tucumán fue la encabezada por la Sociedad de Obreros Panaderos 
que en septiembre de 1900 reclamó el amento de salarios y el mejoramiento de las condiciones de trabajo. El conflicto fue el resultado de la negativa de los patrones a discutir la propuesta presentada por la sociedad gremial de panaderos que reclamaba un aumento salarial para los oficiales y ayudantes y el establecimiento de un sueldo a los maestros que fuera proporcional a su trabajo. Además, los trabajadores pedían 60 kilos de harina por plaza y la supresión de los cargadores en las casas en donde existían. Ante la ausencia de respuestas por parte de la patronal que se negó a discutir el convenio presentado por la asociación de obreros panaderos, estalló la huelga. El lugar de reunión de los obreros panaderos fue el Centro Cosmopolita de Trabajadores, local en el cual funcionaba la Sociedad de Obreros Panaderos y principal ámbito de sociabilidad, cultura y protesta obrera en Tucumán durante el periodo estudiado. El Centro Cosmopolita de Trabajadores ofreció un respaldo explícito a la huelga a través de un manifiesto que circuló a "todas las clases obreras" para que respaldaran a los panaderos huelguistas.

La protesta evidenció el grado de organización del gremio de trabajadores del pan y reveló un amplio nivel de aceptación entre los obreros panaderos, al involucrar la cifra nada despreciable de 300 trabajadores que participaron de la huelga. Además, la protesta testimonió las expresiones de solidaridad obrera, muestras que probablemente se incrementaron al calor de los apoyos recibidos por parte de la Federación que integraba la sociedad de Obreros Panaderos de Tucumán. En esa línea, debemos destacar el respaldo de asociaciones como la sociedad de panaderos del Litoral. También, resulta importante subrayar el apoyo que recibieron los huelguistas de aquellos peones y obreros provenientes de ciudades del interior tucumano, como Monteros, Lules y otras villas de campaña, así como de provincias vecinas como Santiago del Estero. Estos trabajadores arribaron a la ciudad de San Miguel de Tucumán al ser solicitados por los patrones de las panaderías, quienes intentaban suplir la falta de trabajo originada con la huelga. Sin embargo, una vez que llegaron a la capital tucumana, los trabajadores se plegaron a la protesta que manifestó un amplio acatamiento y se prolongó durante dos semanas. Finalmente, la lectura de las noticias difundidas en El Orden sugiere que el conflicto concluyó favorablemente para los trabajadores que obtuvieron las demandas solicitadas. ${ }^{17}$

La lectura de otras fuentes permite conocer aspectos hasta ahora ignorados sobre la huelga. Por ejemplo, que la Federación de la cual formaba parte la asociación de obreros panaderos era la Federación Obrera Local, adherida al anarquismo. Desde esta perspectiva, periódicos de Buenos Aires afines a esta corriente como las publicaciones gremiales $\mathrm{El}$ Obrero y El Obrero Panadero difundieron un relato completamente distinto al circulado por El Orden sobre esta huelga. Y, paradójicamente, mientras El Orden destacó la eficacia, organización y buen resultado de la protesta, los periódicos obreros anarquistas subrayaron los aspectos negativos de esta huelga, criticaron a sus protagonistas y buscaron explicar el fracaso de la misma.

En contraste con las afirmaciones de El Orden sobre el buen resultado de la protesta, de acuerdo con los datos obtenidos en El Obrero Panadero, la huelga no llegó a buen puerto y este desenlace negativo demostraba la falta de conocimientos de los trabajadores tucumanos en cuestiones de suma importancia, como la denominada "cuestión

${ }^{17}$ El Orden, 3/9/1900, 5/9/ 1900, 6/9/1900, 10/9/1900 y 14/9/1900.

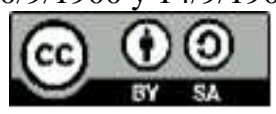


social". Además, el fracaso de la protesta obedecía a la ignorancia, desorganización y la eventual precipitación de los militantes en la provincia. Al respecto, esta fuente se lamentaba del "mal resultado que ha tenido la huelga de Obreros Panaderos que se produjo en Tucumán, motivado por la poca preparación en la cuestión social que tenían los obreros que encabezaron ese movimiento". Asimismo, adjudicaba el fracaso de la protesta a las indecisiones que revelaron los miembros de la Comisión Directiva de la asociación de trabajadores panaderos durante el desarrollo de la huelga, sumado al establecimiento de una cooperativa, instancia cuestionada duramente ya que se la consideraba "el desacierto más tremendo" de una corporación que iniciaba un movimiento de protesta como el comenzado por los obreros en Tucumán. ${ }^{18}$

Al respecto, El Obrero Panadero en un artículo de 1900 dirigido a los compañeros de Tucumán afirmaba,

Un compañero y amigo nuestro en estas mismas columnas ha dicho: "la poca educación, la falta de conocimientos de la cuestión social ha motivado el desbande y la pérdida de la huelga". Y como más va a ser. Para tomar una simple resolución era menester un gran tiempo, porque las indecisiones superaban a la voluntad. Entre tanto los lobos de la burguesía se pertrechaban, y cuando menos se pensó, ya no eran necesarios vuestros brazos para la elaboración de pan, porque había otros trabajadores; aparte de los carneros que se quedaron trabajando. ${ }^{19}$

Las conclusiones opuestas entre sí sobre la huelga que expresaban la prensa comercial provincial y los diarios obreros gremiales se complementaron con otras posturas contrastantes en torno a las capacidades y atributos de los trabajadores del pan en Tucumán. En ese sentido, interesa señalar que mientras El Orden destacaba el buen comportamiento demostrado por los obreros panaderos en huelga, periódicos como El Obrero y El Obrero Panadero insistían en las conductas viciosas y holgazanas de los trabajadores del pan en la provincia. Así, por ejemplo, en una entrevista --modalidad novedosa en la prensa tucumana de la época-- los periodistas de El Orden elogiaban el proceder pacífico y virtuoso de los huelguistas, quienes, por ejemplo, durante sus reuniones en el local del Centro Cosmopolita de Trabajadores debatían tranquilamente y sin beber alcohol. En contraste, los diarios gremiales anarquistas El Obrero y El Obrero Panadero recuperaban los prejuicios y las impugnaciones que pesaban sobre el comportamiento de los trabajadores del Norte argentino y que poblaban las miradas de militantes y dirigentes del socialismo, el anarquismo y el sindicalismo. Una muestra en ese sentido se reflejó en el artículo publicado por El Obrero, que en abril de 1901 describía al trabajador del pan en Tucumán como vicioso, propenso a las bebidas alcohólicas, haragán y poco estudioso.

Aún no ha visto el tremendo desprecio que se le hace a un obrero panadero como en esta ciudad de Tucumán. Aquí el obrero panadero por instinto de conservación es afecto a las bebidas alcohólicas, como también a la más tremenda haraganería, esto es por lo regular y en raras excepciones se verá al

${ }^{18}$ El Obrero Panadero, 31 de octubre de 1900.

${ }^{19}$ Ibid., 22 de noviembre de 1900. 
obrero que se dedique al estudio. El panadero aquí, no tiene más reunión ni más conversación que la adulación y el alcoholismo, esto es, en los almacenes; en el trabajo no hay preocupación para nada y en nada se preocupan para el bien de la humanidad. ${ }^{20}$

Un poco más adelante, la narración de El Obrero extendía la posesión de conductas y hábitos viciosos al resto de la clase trabajadora en la provincia, al afirmar que

Es sabido que en esta ciudad reina una miseria espantosa mucho mayor que en la capital federal; aquí la gente pobre no sabe cómo hacer para poder vivir, infinidad de familias no comen carne y pan tres veces a la semana; todas estas consecuencias es debido al vicio, u la ignorancia en que vive la clase trabajadora, sin preocuparse en nada, ni para nada, del bienestar de la humanidad en general; esta es la ciudad de Tucumán. ${ }^{21}$

Estos discursos teñidos de sospechas y descalificaciones sobre los comportamientos y las costumbres de los trabajadores norteños se completaban con otras descripciones negativas que enfatizaban el desconocimiento, la incapacidad y la falta de organización de estos grupos, rasgos que les impedían construir una militancia idónea, entendida en términos de identificación de intereses comunes, lucha y consciencia de clase.

Aunque con matices y diferencias, esta mirada era, en gran medida, compartida por otras expresiones de izquierda en el mundo del trabajo que través de sus discursos contribuyeron a configurar un tópico recurrente de la época: el trabajador norteño como un sujeto rudimentario, ignorante, vicioso, vago y con poca capacidad para la organización racional y la militancia partidaria. ${ }^{22}$ A modo ilustrativo podemos recuperar las consideraciones vertidas en La Acción Socialista, órgano de expresión del sindicalismo revolucionario, fracción que se separó del socialismo tras divergencias al seno de este movimiento. En artículos dedicados a cuestionar el accionar del líder obrero socialista Adrián Patroni en la organización y conducción de los trabajadores tucumanos durante la gran huelga de peones azucareros de 1904, esta publicación subrayaba en 1906 "la ignorancia de una gran parte de los obreros de los ingenios de azúcar", quienes carecían de "conciencia obrera" y "dignidad de clase". 23 "No había organización ni lucha, no había control proletario de ninguna especie. El proletariado no existía como clase, el obrero no existía como hombre. Eran simples fuerzas productoras, como las mulas, como una máquina", ${ }^{24}$ aseguraba el dirigente sindicalista Luis Lotito quien visitó la provincia en 1905, tras la huelga azucarera y cuyo testimonio sobre el tema fue publicado en una serie de artículos difundidos en La Acción Socialista al despuntar 1908.

\footnotetext{
${ }^{20}$ El Obrero, 13 de abril de 1901.

${ }^{21}$ Idem.

${ }^{22}$ Tomo la idea de la construcción del tópico sobre el trabajador del Norte argentino de Mirta Zaida Lobato, experta en el estudio de las trabajadoras y trabajadores en Argentina en los siglos XIX y XX y autora de numerosas y valiosísimas obras sobre la materia, durante sus comentarios en la Mesa "El mundo de los trabajadores: espacios, actores, cultura y conflictos" de las Jornadas de Historia Social en la Falda, Córdoba, celebradas en mayo de 2015.

${ }^{23}$ La Acción Socialista, 1 de junio de 1906.

24 "El proletariado tucumano", La Acción Socialista, 16 de enero de 1908.
} 
Por otra parte, es factible pensar que los cuestionamientos a los trabajadores tucumanos se conjugaban con las luchas ideológicas y enfrentamientos al interior de las fuerzas de izquierda en el mundo del trabajo. En ese sentido, las disputas entre socialistas y anarquistas conformaban un lugar común del derrotero de prácticas militantes. Básicamente, desde la óptica del anarquismo, las críticas principales apuntaban al accionar de los socialistas y, en esa dirección, al carácter político de las prácticas de los trabajadores. En esos parámetros podemos situar la descripción tendenciosa y descalificadora de $E l$ Obrero que luego de criticar enérgicamente a los trabajadores de Salta y de Jujuy se detenía en el caso tucumano para afirmar que

Tucumán es una ciudad más grande que Salta y Jujuy juntos. Pero como es grande, así es de grande la Ignorancia de los habitantes, esto es por lo regular. El movimiento obrero está completamente paralizado en todo y por todo; aquí. Hay una Sociedad Cosmopolita de Trabajadores y un Club Católico, el primero marcha con fines políticos y el segundo al retrógrado en toda la extensión de la palabra! religión y basta!... La sociedad de panaderos está muerta, debido a la cobardía y al poco espíritu de sociabilidad que reina en el mencionado gremio. Hasta qué grado llegará la cobardía del panadero que hoy en día cuando trabajan diez días, les parece que ya son ricos y al pío de la letra se largan como caravanas a los boliches hasta fundir los pocos centavos que han ganado. He aquí las provincias del Norte. ${ }^{25}$

La crítica fundamentaba su argumentación en la ignorancia que caracterizaba los comportamientos de los trabajadores tucumanos en el marco de un asociacionismo obrero limitado, restringido al campo de la política y la religión. A su vez El Obrero se detenía en el caso puntual de los panaderos a quienes describía como un gremio de cobardes y vagos. De esta forma, el periódico gremial concluía su pintura negativa y poblada de prejuicios sobre el trabajador del Norte argentino. Con lo cual, podría no ser más que aparente la paradoja que planteábamos anteriormente entre los comentarios positivos sobre la huelga difundidos en $\mathrm{El}$ Orden y las miradas condenatorias al accionar de los huelguistas detectadas en las páginas de El Obrero y El Obrero Panadero. Es muy posible que tales impugnaciones obedecieran precisamente al abanico de prejuicios, sospechas y descalificaciones que recorrían las descripciones de los líderes anarquista --y, como vimos hace unos momentos, de otras expresiones de izquierda en el mundo del trabajo, como el sindicalismo-- en torno a las conductas y atributos de los trabajadores tucumanos.

Otra interpretación plausible remite a la misma división al interior del movimiento anarquista tensionado por la puja de distintas tendencias y fracciones. Al respecto, resulta interesante recuperar el análisis que realizó Lucas Poy para Buenos Aires y, en particular, sus señalamientos acerca de la estrecha vinculación que mantuvo desde sus orígenes la sociedad de resistencia de obreros panaderos con el movimiento anarquista. Un elemento muy importante a destacar --propone Poy-- es como más allá de la fuerte impronta libertaria, "la sociedad de panaderos tenía roces y disputas con otros grupos anarquistas activos en el periodo. Las principales divergencias eran las que se planteaban con los

${ }^{25}$ El Obrero, 21 Julio de 1901. 
anarquistas de orientación anti-organizadora, que consideraban que la sociedad de panaderos tenía rasgos autoritarios incompatibles con las ideas libertarias e incluso [...] cuestionaban la utilidad misma de las luchas reivindicativas y las huelgas". ${ }^{26}$

Teniendo en cuenta las tensiones al interior del anarquismo es factible pensar que los militantes libertarios que escribían en El Obrero y El Obrero Panadero no simpatizaron con las prácticas de los anarquistas tucumanos que interactuaban con los trabajadores afines al socialismo en un mismo espacio obrero, como el Centro Cosmopolita de Trabajadores. Por el contrario, tiene sentido suponer que esta misma mixtura entre socialistas y anarquistas que convivían en un espacio común promovió el apoyo del diario El Orden que en ningún momento definió a los obreros panaderos en huelga como expresión del movimiento anarquista.

No obstante lo anterior, también es cierto que las publicaciones gremiales libertarias El Obrero y El Obrero Panadero rescataron la importancia de la huelga de obreros panaderos en Tucumán como parte de un proceso de aprendizaje militante y elogiaron los esfuerzos de los trabajadores tucumanos en esa dirección. Con lo cual, además de las críticas las páginas de la prensa obrera anarquista difundieron también un mensaje positivo y de respaldo al gremio del pan en la provincia. Veamos algunos pasajes.

Desde Tucumán

El Obrero Panadero, Buenos Aires.

En la larga y ruda lucha que en esta hemos sostenido, si no hemos logrado todo lo que deseábamos, al menos hemos despertado, el compañerismo en la clase obrera en general que no estamos tan inconscientes como en otros tiempos, sino que ya vamos conociendo poco a poco nuestros derechos y que trataremos tarde o temprano de recobrarlo. Nuestro explotado gremio, tiene que luchar doblemente y esta es causa de la inconsciencia que aun reina en algunos compañeros, que tratan de tener contento al patrón donde trabajan aunque para esto tengan que violar las reglas del compañerismo y de la Sociedad; son estos, felizmente algunos pocos, que tratan de destruir nuestra Asociación, de perjudicar a todos los compañeros más conscientes y competentes y de emponzoñar y dirigir por mal camino a todos los que tienen contacto con ellos. ${ }^{27}$

A los compañeros de Tucumán

Si hay espíritu de hombres en vuestros pechos, no debéis desmayar ante la pérdida de la huelga ultima, porque si bien es cierto que ella importa un mal paso dado en el camino de nuestra marcha, es también una lección que se aprende de memoria y se va mas tarde a rendir examen ante el concurso de la justicia. La Sociedad de resistencia que después de arduos esfuerzos habéis formado, debe tomar otro rumbo, e inspirándose en el Ideal de nuestra emancipación, estudiar los medios de lucha. Entonces no andaréis vacilantes, vuestras decisiones serán firmes y seguras, vuestro triunfo infalible. ${ }^{28}$

\footnotetext{
${ }^{26}$ Lucas, Poy, Los orígenes de la clase obrera argentina. Huelgas, sociedades de resistencia y militancia política en Buenos Aires, 1888-1896, Buenos Aires, Imago Mundi, 2014, 204-208.

${ }^{27}$ El Obrero Panadero, 31/10/ 1900.

${ }^{28}$ Ibid., 22/11/1900.
} 


\section{"Belicosos dependientes". Los disturbios de 1912}

A finales de 1912, los dependientes de comercio protagonizaron una violenta protesta contra sus patrones que incumplían sistemáticamente la ley que establecía la obligatoriedad de cerrar los establecimientos comerciales a las ocho de la noche. Según la narración proporcionada por El Orden, desde poco antes de las 20 horas, un grupo de dependientes de comercio se había reunido frente al bar Centenario, localizado en el centro de la ciudad y desde allí se desplazaron hacia los distintos locales que permanecían abiertos después del horario permitido por la ley. Uno de estos establecimientos, la zapatería "La Catalana", propiedad de los señores Coralina y Puig, que funcionaba en uno de los puntos más céntricos de la ciudad, la esquina de la calle 24 de septiembre con la calle 9 de julio, fue objeto de duros ataques. Los trabajadores ingresaron al local que se hallaba con las vidrieras cerradas mientras que las puertas permanecían abiertas.

Los dueños de la zapatería se hallaban cenando. De pronto se oyeron estruendosos vivas, pero ello no puso en cuidado a la familia del señor Puig, pues creyó que se trataba de una manifestación política. Grande fue la sorpresa al ver penetrar a un considerable grupo de individuos al negocio, los que decían: ¡Que se cierre! ¡Que se cierre, y arrojaban a la vez pedradas en todas las direcciones. Las pedradas llovían, quebrando vidrieras y derrumbando cajas de botines. Una sirvienta de nombre Carmen Olea, recibió un golpe en el pie izquierdo, que le produjo una contusión leve. En la forma que tiraban las piedras, podían muy bien haber muerto a cualquiera, pegándole en la cabeza. ${ }^{29}$

Posteriormente, y de acuerdo al relato de la prensa, un local, la joyería del señor Francisco Yanicelli, logró impedir el asalto de que iba a ser víctima al cerrar rápidamente sus puertas. Luego, la columna de trabajadores continuó su recorrido protestando contra cada comercio que encontraron abierto más allá del horario estipulado por la ley. Uno de esos establecimientos, una tienda localizada entre la calle Maipú y Muñecas, no sufrió mayores perjuicios y sus dueños "huyeron temerosos de ser heridos de alguna pedrada". Una suerte distinta corrió la peluquería del señor Walfando Iglesias, situada en calle Las Heras al 700, en donde laboraba un empleado que, según aseguraba El Orden, al no simpatizar con las ideas de los dependientes no quiso participar de la manifestación. Allí, las pérdidas fueron mayores que en la zapatería "La Catalana", ya que sus cristales resultaron rotos y los frascos de loción y otros objetos quedaron inutilizables. Finalmente, y aprovechando -afirmaba el diario- la falta de respuesta de las autoridades y de los propietarios, los dependientes llegaron a la zapatería del señor Rafael de Camilo ocasionando un desorden de mayores proporciones. Los "belicosos dependientes", como los denominó El Orden, "siempre con el mismo ímpetu, atropellaron la zapatería en medio de una gritería infernal, arrojando piedras a diestra y siniestra". 30

${ }^{29}$ El Orden, 6/11/1912.

${ }^{30}$ Ibidem. 
La protesta pasó a mayores. Intervino la policía y detuvo a los manifestantes que consideró más comprometidos. En total resultaron aprehendidos 10 dependientes de comercio, reputados como cómplices de los disturbios producidos. La resolución de la policía fue liberar a "un propagandista libertario, creyéndoselo mezclado en el asunto, por haberse justificado que no lo estuvo". Paralelamente, la repartición policial estipuló que uno de los presos sobre el cual recayó la acusación de ser el "mayormente comprometido" sea "expulsado de la provincia por sus ideas avanzadas". ${ }^{31}$ Como se desprende de la información consultada, tal fue el caso de Ángel F. Derisso, quien al ser considerado como el principal activista de esta protesta fue sancionado con la Ley de Residencia. Sin embargo, una lectura de las fuentes permite suponer que tal medida no se llevó a cabo o bien que Derisso logró tiempo después esquivar la vigilancia y control de la ley para retornar a la provincia. Lo anterior explicaría que durante las movilizaciones anarquistas desarrolladas para evocar el $1^{\circ}$ de mayo de 1916 observáramos a Derisso intervenir como uno de los oradores centrales. ${ }^{32}$

Aunque no es tarea sencilla reconstruir el itinerario de este militante libertario debido principalmente a la escasez de fuentes sobre el tema, a través de una nota reciente publicada por Carlos Páez De la Torre en el diario local La Gaceta, podemos aportar algunos datos.

Básicamente, los aspectos revelados sobre la vida de Derisso se apoyan en un reportaje que le realizó a este activista la conocida revista Fray Mocho. A partir de esta publicación sabemos que Derisso residió durante algún tiempo en Tucumán y que allí laboró en la peluquería propiedad de un individuo apellidado Quiroga. Una de las facetas de la personalidad de Derisso reveladas en la entrevista fue la estrecha vinculación entre el oficio de peluquero y la vocación por el periodismo, según afirmaba el mismo entrevistado, para quien no era nada extraña la alianza de la tijera con la pluma. "Un peluquero intelectual" fue precisamente la expresión que utilizó en el subtítulo de su nota en La Gaceta Páez De la Torre, al tiempo que señala: "además de su oficio de tijera y navaja era periodista y eficaz orador en los mítines políticos”. Asimismo, a partir de la información proporcionada por el reportaje de Fray Mocho y recuperado por Páez de la Torre en su crónica, conocemos el lugar de nacimiento de Derisso: Buenos Aires, y nos aproximamos a algunas aristas de su accionar en el ámbito de la prensa, ejemplificadas con la fundación del periódico de combate La Antorcha, creado en 1912 en la ciudad de Santa Fe. Según el relato de la entrevista, a partir de entonces Derisso comenzó a pasar temporadas en peluquerías de distintas provincias, como Santa Fe, Córdoba, Mendoza, Salta y Tucumán, "de donde acaba de regresar al pago con boleto facilitado por la policía, empeñada constantemente en "darle" con el gusto como un homenaje a su espíritu andariego y romancesco. ${ }^{33}$

Finalmente, el periodista de Fray Mocho especulaba sobre el pensamiento de Derisso, poblado "de visiones fantásticas", de "un mundo nuevo, aureolado por la igualdad de todos los hombres". Añadía el entrevistador que Derisso se declaraba voraz lector de todos los autores, sin predilección por ninguno en particular y señalaba que en el gremio se

\footnotetext{
${ }^{31}$ Ibid., 6/11/1912 y 7/11/1912.

${ }^{32}$ Ibid., 3/5/1916.

33 “Apenas Ayer, De la Tijera y la pluma. Ángel F. Derisso, un peluquero intelectual”, La Gaceta, 2015.
} 
conocía a Derisso con el apodo de Centenario. Por último, el reportaje retrataba a Derisso como "un personaje que sale completamente de lo vulgar, lo que le permite mirar con menosprecio las cabezas humanas que caen bajo la acción del filoso instrumento, porque las sabe, en su mayoría inferiores a la suya". ${ }^{34}$

Hasta aquí los datos sobre Ángel F. Derisso. Sobre la filiación de los trabajadores peluqueros con el anarquismo conviene realizar algunas presiones. Por ejemplo, apuntar que dos años después de esta protesta, en 1914, en el contexto de crecimiento del movimiento libertario en la provincia a través de una mayor presencia en el mundo de los gremios, los oficiales peluqueros resolvieron ingresar a la Sociedad Oficios Varios, adscripta a la Federación Obrera Local Tucumana, hasta tanto existiera un núcleo mayor de 30 oficiales, cifra que les permitiría formar parte de la Federación directamente. Para ello, resolvieron nombrar como delegados a dos compañeros. A su vez, acordaron lanzar un manifiesto invitando al gremio a abandonar el trabajo el $1^{\circ}$ de mayo y concurrir al mitin de la Federación Obrera en la Plaza Alberdi. Por último, los oficiales peluqueros sometieron a discusión un pliego de condiciones para presentar a los patrones a finales del próximo mes, en el cual reclamaban la jornada máxima de 8 horas y un sueldo mínimo de 3,50 pesos diarios. $^{35}$ Estas consignas no eran datos menores, en la medida que se trataba de una protesta laboral específica presentada por un gremio a la patronal durante la jornada del $1^{\circ}$ de mayo. Además, constituyó la primera evidencia concreta de la decisión de los trabajadores de no laborar durante dicha efeméride. Con el tiempo, la costumbre de no trabajar los primeros de mayos alcanzaría mayor fortaleza y se impondría en el repertorio de prácticas obreras.

Ya para terminar, y volviendo a la protesta de los dependientes de comercio en 1912 quisiera contextualizarla el marco de las consideraciones difundidas en la época sobre el anarquismo como un movimiento violento y peligroso que originaba los mayores conflictos obreros y sociales de la época. Más allá del alcance real de esta percepción, lo que me interesa sugerir --en rigor de verdad-- es cómo al responsabilizar de la protesta de los dependientes de comercio en Tucumán a uno o dos individuos reputados "peligrosos", los grupos dominantes evitaban contemplar seriamente los problemas laborales que se suscitaban ante la falta de cumplimiento de los comerciantes de las normativas y leyes de trabajo. No obstante, este recurso duraría poco tiempo. Años después, las estrategias de los propietarios para violar las leyes y tener sus negocios abiertos después del horario acordado motivó nuevas protestas por parte de los trabajadores en un contexto de recrudecimiento de las tensiones y enfrentamientos sociales y laborales entre 1917 y 1919, pero esto ya es materia de otro trabajo.

\section{Veladas y publicaciones anarquistas}

Al igual que el socialismo, el anarquismo organizó veladas de carácter cultural y social para fomentar la difusión de la propaganda obrera y estimular la construcción de militancias entre los trabajadores tucumanos. Asimismo, los anarquistas participaron de conferencias

\footnotetext{
${ }^{34}$ Idem.

${ }^{35}$ La Gaceta, 29/04/1914.
} 
sobre un conjunto extenso de temas, como democracia social, cuestión social, organización gremial, etc. Dentro de las fiestas anarquistas sobresalió sin duda la tertulia literariomusical desarrollada en 1907 en las instalaciones del teatro Belgrano. La fiesta, organizada por la Federación Obrera Local Tucumana (FOLT), central de impronta anarquista, formada en 1906 con sociedades de trabajadores de la ciudad de San Miguel de Tucumán, ${ }^{36}$ incluyó discursos, cantos revolucionarios y declamaciones poéticas. Definido como un acto de carácter libertario dedicado a las clases trabajadoras, el evento festivo contó con la presentación del coro de la Federación y del Orfeón Libertario, poesías y palabras a cargo de dirigentes provinciales y delegados de la Federación Obrera de la República Argentina (FORA) que respondía al anarquismo. Al respecto, citamos el programa previsto para la velada:
Programa
$1^{\circ}$ Sinfonía por el Orfeón Libertario
$2^{\circ}$ Discurso de apertura por el compañero Tomas Delgado, de la Federación Obrera Local
$3^{\circ}$ Hijos del Pueblo por el coro de la Federación
$4^{\circ}$ Conferencia por el delegado de la FORA, compañero Francisco Sánchez sobre la vida y el ideal proletario
$5^{\circ}$ El precioso monólogo El Atentado, desempeñado por el compañero Gioveti
$6^{\circ}$ La Marsellesa, por el Orfeón Libertario
$7^{\circ}$ Conferencia por el compañero H. Louevre, delegado de la FORA, sobre el tema: "quiénes somos y qué queremos"
$8^{\circ}$ Declamación por los niños Pérez, de las poesías "Mi Bandera" y "Los Parias". ${ }^{37}$

La lectura del programa permite sugerir la semejanza entre las fiestas socialistas y las anarquistas, evidenciada a través de la elección común de himnos de carácter revolucionario, poesías y obras de teatro enmarcadas en el tono de denuncia social y de protesta. Esta coincidencia ya fue señalada por especialistas en el tema, como Juan Suriano, quien en su excelente libro sobre el anarquismo en Buenos Aires sostiene que a pesar de las diferencias doctrinales entre el socialismo y el anarquismo, ambas tenencias presentaron un patrón semejante de veladas culturales, en donde los himnos, las canciones, las piezas de teatro y el repertorio temático de las conferencias no reconocían una distancia muy marcada. ${ }^{38}$

Por supuesto había variaciones y tanto el nombre de los oradores como los títulos de los poemas, canciones y representaciones teatrales permitían inferir las filiaciones anarquistas o socialistas de las fiestas. No obstante, todas ellas aspiraban a un objetivo común: difundir, educar y propiciar la creación de militancias entre los trabajadores, para lo cual era fundamental instruirlos en los intereses de clase, estimular su lucha y delinear una cultura obrera contestataria.

\footnotetext{
${ }^{36}$ El Orden, 27/9/1907.

${ }^{37}$ Idem.

${ }^{38}$ Suriano, 2001, op. cit., p. 69.
} 
Ahora bien, esta cultura obrera que tanto el socialismo como el anarquismo aspiraban a forjar no era --claro está-- la misma. Es sabido que ambos movimientos diferían en no pocos asuntos relacionados con la vida asociativa, entre los cuales sobresalía la discusión en torno a la importancia de la participación política de los trabajadores, instancia propiciada por el socialismo y cuestionada en cambio por el anarquismo. Otros tópicos que generaban discrepancias entre ambas corrientes se vincularon con temáticas concernientes a la sindicalización de los trabajadores, el carácter que se buscaba conferir a las protestas, en especial el papel central otorgado a la huelga general percibida como una herramienta transformadora de la sociedad, la relación de los trabajadores con otros grupos sociales y el recurso a la violencia.

Finalmente, y a pesar de la escasa y fragmentaria información disponible sobre el anarquismo en Tucumán durante el periodo bajo estudio, es factible reconstruir, aunque sea brevemente, el perfil social de algunos de sus dirigentes. En esa dirección, sobresale el caso de Tomas Delgado, el dirigente de la FOLT que pronunció el discurso de apertura en la velada mencionada hace unos momentos. Sin duda Delgado fue una figura clave del anarquismo en la provincia durante el periodo formativo del movimiento obrero y, tal como sabemos, intervino en varias movilizaciones obreras de la época. Por ejemplo, entre las actuaciones de este líder anarquista en Tucumán se destacó su participación como orador en la manifestación realizada en 1907 para respaldar una de las principales demandas de los trabajadores en la primera década del siglo XX: la ley de descanso dominical, y protestar contra el decreto reglamentario que limitaba el beneficio de esta ley. Esta movilización encabezada por la FOLT y la Confederación del Trabajo en Tucumán, central que respondía al socialismo, alcanzó gran difusión entre las sociedades gremiales tucumanas: asociaciones de dependientes de comercio, panaderos, mozos, sastres, peluqueros, alpargateros, carpinteros, albañiles, constructores de carruajes y ferrocarrileros participaron de la protesta, al tiempo que los dependientes de comercio de ciudades del interior tucumano, como Monteros y Concepción, enviaron notas de adhesión a la misma. ${ }^{39}$

\section{Los discursos de Germinal en torno al $1^{\circ}$ de mayo}

El dirigente libertario Tomás Delgado tuvo también un papel protagónico en la revista anarquista Germinal, editada como un número único por la Federación Obrera Local Tucumán con la ocasión de conmemorar el $1^{\circ}$ de mayo de $1908 .{ }^{40}$ En uno de los artículos que llevaba su firma, Delgado aseguraba que

\footnotetext{
${ }^{39}$ El Orden, 7/09/1907.

40 Según Bilbao, op. cit., 143-151, Tomás Delgado fue probablemente el único autor de los artículos aparecidos en Germinal. Para la reconstrucción biográfica de otros dirigentes y militantes que desempeñaron un papel clave en las iniciativas de los centros socialistas y anarquistas en la provincia una obra sumamente valiosa es el Diccionario biográfico de la izquierda argentina. De los anarquistas a la nueva izquierda (18701976), dirigida por Horacio Tarcus. Allí, encontramos completas referencias sobre líderes de izquierda como, por ejemplo, Gregorio Pinto, “dirigente socialista que se instaló en la ciudad de Tucumán, donde fue designado, por el PS y la UGT, delegado permanente ante la organización de los obreros de los ingenios". También el libro dirigido por Tarcus contiene información sobre el renombrado anarquista italiano Pietro Gori, quien vivió en Buenos Aires entre 1898 y 1902 y visitó Tucumán al despuntar el 900 como parte de las
} 
El $1^{\circ}$ de mayo es, pues, para nosotros un punto de partida que gesta las grandes rebeldías contra este régimen de eunucos, envuelto en las más bárbaras criminalidades. Es necesario, entonces, que rindamos culto a los que cayeron luchando por las conquistas humanas; pero no un culto fanático que extravíe las mentalidades; solo un culto de amor sincero, que salude en cada aniversario a los mártires de la idea.

Proletarios tucumanos: no olvidéis jamás los sombríos espacios de las ¡horcas malditas! Y que de nuestras bocas salga un ¡Viva a los mártires de la idea! $!^{41}$

A través de un tono virulento y del empleo de expresiones recurrentes del lenguaje anarquista en torno al $1^{\circ}$ de mayo, tales como "horcas malditas", los "mártires de Chicago", etc., Delgado concluía sus artículos llamando la atención específica de los "proletarios tucumanos" a quienes instaba a recodar el verdadero sentido de la efeméride obrera. Las referencias, ya sean explícitas o más veladas, eran siempre en contraposición al significado otorgado por el socialismo al Primero de Mayo. En esa dirección, Tomas Delgado, al igual que otros militantes que escribieron en Germinal, distinguían la conmemoración libertaria de la fiesta socialista, definida como una instancia de "farras y orgias". De esta forma, en otra nota que llevaba su firma y se titulaba "La voz de mayo", Delgado afirmaba

Y es por esto que en el día $1^{\circ}$ de Mayo, único día del año que amontonamos nuestras víctimas: llamamos que es un día de protesta no un día de farras y orgias como pretenden ciertas nulidades que pululan dividiendo la finalidad grande de los trabajadores. No es tampoco un día de luto en que los ácratas conmemoremos como los católicos el día de los difuntos, no, pero sí debe ser un día en que los brazos productores de la riqueza social paren en toda la extensión de la tierra para hacer ver a la burguesía que el despotismo y su obra salvaje contra los trabajadores, será chayubar a nuestra emancipación y hacer empuñar con más energías las piquetas que ha de demoler todo este castillo ruinoso y construir el palacio sí, el palacio de la felicidad humana. Trabajadores tucumanos saludemos con nuestro pañuelo rojo al Mayo 1, germen de nuestra libertad. ¡Loor a los mártires de Chicago! ${ }^{42}$

Como es sabido, el movimiento libertario no era un bloque compacto y existían distintas tendencias y corrientes en su interior, lo cual lleva a proponer a numerosos investigadores sobre el tema el empleo del término de "anarquismos" en vez de su uso en singular. ${ }^{43}$ Sin embargo, y como bien lo señalan Clara E. Lida y Pablo Yankelevich en un libro reciente "lo que desde sus orígenes dominó en lo que genéricamente llamamos

giras que realizaba en el país (Tarcus, Horacio, Diccionario biográfico de la izquierda argentina. De los anarquistas a la nueva izquierda (1870-1976), Buenos Aires, Emecé Editores, 2007, pp. 286-287 y 514).

41 "Historiando los hechos", Germinal, 1 de mayo de 1908.

42 "La voz de mayo", Germinal, 1 de mayo de 1908.

43 Lida, Clara E. y Yanquelevich, Pablo, "Presentación", Lida, Clara E. y Yanquelevich, Pablo, (compiladores), Cultura y política del anarquismo en España e Iberoamérica, México, El Colegio de México, 2012, 9-25. 
anarquismo [...] es un movimiento social, orientado a la organización de las clases populares, especialmente las trabajadoras, con el fin de llevar a cabo una revolución para transformar entre otras, las desiguales relaciones sociales, políticas y económicas." 44

Teniendo en cuenta estas consideraciones, es factible leer a través del discurso de Tomás Delgado sobre el Primero de Mayo algunas de las ideas centrales de las consignas anarquistas de la época. El combate a los socialistas, en tanto adversarios en el campo de la organización y el liderazgo de los trabajadores y el repudio a accionar de los poderes del Estado y de la iglesia católica, percibidos como los grandes explotadores de los trabajadores y del resto de los oprimidos se inscribían entre los anhelos fundamentales del anarquismo que aspiraba a la transformación social por vía del triunfo sobre la sociedad capitalista y los pilares sobre los que ésta se fundaba. Al respecto seguimos a un especialista sobre el tema en Argentina, Juan Suriano, quien señala que la impugnación de la sociedad capitalista que buscaba el anarquismo implicó un cuestionamiento tajante al autoritarismo, el patriotismo, el militarismo y el clericalismo y la formulación de un proyecto cultural que aspiraba a educar a los trabajadores y conformar nuevas identidades con un contenido iluminista y racional. Tal como sostiene Suriano, se suponía que mediante las ideas racionalistas y la ciencia, los hombres dejarían atrás el oscurantismo religioso y la explotación económica. ${ }^{45}$

No obstante lo anterior, tiene sentido suponer que para el anarquismo había hombres más preparados que otros. A juzgar por los documentos analizados, podemos suponer que los trabajadores del interior argentino, como Tucumán, contaban con escasas posibilidades de alcanzar la liberación y la emancipación necesaria, ya que estaban dominados por rasgos atávicos y entre sus comportamientos primaba la ignorancia y la desorganización. Desde esa óptica, es posible interpretar ciertas expresiones que denostaban el marcado desprecio y la descalificación con las cuales algunos líderes anarquistas juzgaban las prácticas de los militantes locales. Así, en una breve nota en la cual Tomás Delgado aparentemente se despedía de los trabajadores de Tucumán, el dirigente obrero fundamentaba su partida de la provincia en la incompetencia de los tucumanos "pseudo libertarios, ignorantes en todo el sentido de la palabra [que] obstaculizan la acción de los que trabajan, de los que luchan sin ningún interés rastrero". 46 Así, finalizaba su estadía de dos años en la provincia, durante la cual, según aseguraba Delgado, había luchado por difundir su conocimiento y experiencia entre los "esclavos" de este suelo.

Pero Tomás Delgado no dejó la provincia. Tenemos evidencias de su participación en otras movilizaciones obreras, como aquellas realizadas en 1910 para conmemorar el $1^{\circ}$ de mayo. A través del relato difundido en las páginas de La Acción Socialista, contamos con referencias sobre la intervención de Delgado en el asociacionismo tucumano. Mediante una narración teñida de descalificaciones y críticas en torno al dirigente libertario, La Acción Socialista comentaba la conferencia desarrollada en mayo de 1910 para aprovechar la llegada a la ciudad de San Miguel de Tucumán del delegado de la Confederación Obrera Regional Argentina (CORA), Sebastián Marotta. En esa ocasión, la sociedad de carpinteros

\footnotetext{
${ }^{44}$ Lida y Yanquelevich, op. cit., 9-25.

45 Juan Suriano, "Las prácticas culturales del anarquismo argentino", Lida y Yanquelevich, op. cit., 145-74.

46 “Al descanso", Germinal, 1908, 1 de mayo de 1908.
} 
convocó a una disertación a cargo de dicho dirigente en la plaza Humberto I. a las 4.30 p.m. del día $1^{\circ}$ de mayo. Allí,

Ante una concurrencia bastante regular, el conferencista desde una tribuna improvisada explicó el verdadero significado de la fecha proletaria, que no es -dijo--día de jolgorio como algunos pretenden hacerlo creer, ni de tristeza y luto como otros afirman, sino de afirmación, de esperanza en el triunfo del proletariado. Explicó las ventajas que se consiguen con la organización, hablando cerca de cuarenta minutos. Varias veces durante la conferencia y al terminar esta, fue estruendosamente aplaudido. ${ }^{47}$

Según esta fuente, el delegado de la CORA

fue aplaudido por la concurrencia excepto por tres o cuatro burgueses allí presentes y tres anarquistas que gritaron ;abajo el trapo rojo! Felizmente nadie les llevó el apunte, ni tampoco les hizo caso, por lo cual no hubo que lamentar ningún incidente que podría muy bien haber ocurrido a no mediar esta circunstancia. La actitud de estos individuos que desprecian el trapo rojo después de haberlo ensalzado en todos los tonos en otras ocasiones, sorprendió a los que no los conocen de cerca pero no a los que tuvimos ocasión de convencernos una vez más de que el cerebro de estos pseudosrevolucionarios no se cristaliza, evoluciona, constantemente. ${ }^{48}$

Tras esta narración que criticaba por igual a "burgueses" y a militantes de otras corrientes de izquierda como el anarquismo, el corresponsal de La Acción Socialista hacía referencias explícitas al dirigente libertario Tomás Delgado.

Tomas Delgado ¡el ya célebre don Tomas! que intenta organizar gremios en esta, haciendo propaganda en ese sentido, que fue secretario de la F. Local y después delegado al congreso de La Plata, se convirtió luego en un intransigente individualista olvidando sus teorías cuando una bella donna así lo exigió; siguiendo esta evolución continua, no es difícil que en cualquier día insulten a sus ídolos los mártires de Chicago y terminen haciendo por fin el monaguillo en cualquier procesión católica. Por esto no nos extraña que hayan dado gritos hostiles contra el trapo rojo los otros dos que se prestaron a servir de comparsas de don Tomás son de una insignificancia tal que no merece la pena tomarlos en cuenta. ${ }^{49}$

"Pseudo-libertarios" llamaba Delgado a los militantes anarquistas tucumanos, "pseudo revolucionarios" eran, por otra parte, para el sindicalismo, anarquistas como Delgado. Distintas facetas del asociacionismo obrero intervenían en estas narraciones descalificadoras, contundentes y que se arrogaban la posesión de verdad. La lucha al interior del movimiento obrero entre miembros de distintas tendencias detonaba la

\footnotetext{
${ }^{47}$ La Acción Socialista, 14 de junio de 1910.

${ }^{48}$ Idem.

${ }^{49}$ Idem.
} 
virulencia del lenguaje y la descalificación a todos aquellos considerados como adversarios. Lógicas facciosas, enfrentamientos partidarios y posturas divergentes en torno a los procesos sociales, económicos y políticos originaban narraciones opuestas entre sí y fomentaban numerosos artículos redactados con ánimo de criticar e impugnar al contrincante.

Además, existían otro tipo de móviles y de disparadores que alentaban estos discursos plasmados en las publicaciones gremiales, obreras y partidarias. En estos casos -estimo- las razones podían ser menos explícitas y más subterráneas. Me refiero a la mirada descalificadora sobre los comportamientos y atributos de los trabajadores del interior argentino que recorría buena parte de las miradas de los líderes obreros, las cuales confluían en las críticas a la clase trabajadora tucumana, menospreciada y juzgada negativamente. Se construía así un tópico: el trabajador del norte argentino como un sujeto que condensaba vicios y defectos. A través de prejuicios y descalificaciones, los trabajadores de las provincias argentinas, consideradas a su vez como atrasadas, recibían los calificativos de vagos, incapaces, irracionales, etc. Lamentablemente, incluso hoy en día muchos de estos calificativos permean sin tapujos las descripciones sobre los trabajadores que habitan o provienen de Tucumán y otras provincias del norte argentino.

Para recapitular y avanzar algunas cuestiones. En la revista Germinal pueden leerse las concepciones y definiciones de los militantes anarquistas acerca del $1^{\circ}$ de mayo, entendido como un día de protesta y de lucha, opuesta a la noción de fiesta que, según afirmaban los miembros del anarquismo, pretendían asignarle al Primero de Mayo los socialistas. Al respecto, son ilustrativas también las palabras plasmadas en el artículo firmado con el seudónimo PVP, que probablemente pertenecían -tal como proponía Santiago Bilbao en un trabajo pionero sobre Germinal- al dirigente anarquista Tomás Delgado. Allí, Delgado afirmaba que el primero de Mayo no era un día de fiesta como pretendían los socialistas sino una jornada de "recordaciones y de protestas". 50 En ese mismo afán de diferenciarse de los socialistas y posicionarse como la fuerza capaz de transformar las injusticias y explotaciones que sufría la clase trabajadora, el militante anarquista aseguraba que la modalidad de conmemorar el Primero de Mayo no era como la elegida por el socialismo que ocupaba las plazas y marchaba ordenada y pacíficamente por las calles de la ciudad. Por el contrario, el anarquismo proponía exigir, reclamar por una sociedad más justa y libre.

Y por eso no iremos a las plazas públicas en procesión apacible y decorativa, quede ello para los socialistas, los arlequines y los amantes del orden estatal. Nosotros los anarquistas no debemos servir de distracciones y solaz para la clase opresora y rapaz, saldremos a la calle no para cantar nuestros dolores en estrofas sentimentales sino para hacer algo más que todo eso, para exigir la parte que nos corresponde en este banquete social al que aportamos todo el caudal de nuestras energías y todo lo que se expone en la mesa. Y decimos para exigir la parte que nos corresponde porque no somos - como lo creen toda la turba de idiotas que defienden el capital- los que queremos acapararlo todo en provecho exclusivo nuestro sino únicamente que cada uno trabaje y

50 "El 1 de Mayo", Germinal, 1908, 1 de mayo de 1908. 
produzcan para que puedan comer, ayudándonos a complementar la vida y a embellecerla, viviendo en la comunidad libre de los hombres libres. ${ }^{51}$

Finalmente, el autor de este escrito concluía afirmando que el verdadero significado del Primero de Mayo era el de un "día de recordación y de afianzamiento de fe. Este es el provecho que debemos sacar de este día, afianzar el carácter y la convicción, hacer un resumen de lo que hemos hecho durante un año y fortalecer el espíritu y afianzar el peso en la senda de la verdadera lucha". 52

En una tónica semejante al artículo anterior, Germinal difundió otras notas que narraban la historia del $1^{\circ}$ de Mayo y enfatizaban su carácter de día de protesta, evocación y duelo. Así, por ejemplo en un escrito firmado por J. Guerra, la efeméride era caracterizada como un eslabón de la gesta de lucha social y no como un momento festivo y caricaturizado, de acuerdo con las críticas del anarquismo a las movilizaciones convocadas por el socialismo para recordar el Primero de Mayo. ${ }^{53}$

\section{Consideraciones finales}

Con el fin de contribuir al conocimiento de un terreno de estudio inexplorado por la historiografía provincial referido al asociacionismo obrero en Tucumán entre finales del siglo XIX y comienzos del XX, en este trabajo nos propusimos examinar las expresiones anarquistas, particularmente sus prácticas de protesta para mejorar las condiciones de trabajo y las manifestaciones destinadas a evocar sucesos claves de la gesta obrera, como el Primero de Mayo.

Respecto a las protestas de los trabajadores, puntualmente aquellas en las cuales fue posible detectar la participación de activistas libertarios, como la huelga de los obreros panaderos, uno de los reclamos más significativos en la provincia al despuntar el novecientos, interesa destacar la solidaridad entre los afiliados a la Federación Obrera Local y la influencia que reveló la protesta. A su vez, resulta importante recuperar las distintas apreciaciones sobre la huelga que se expresaron en la prensa provincial encabezada por El Orden que elogió el comportamiento de los trabajadores huelguistas, en contraste con la mirada más crítica y cuestionadora que detectamos en diarios gremiales anarquistas como El Obrero y El Obrero Panadero.

En cuanto a las distintas valoraciones sobre la huelga en el trabajo sugerimos algunas interpretaciones. La primera, referida a las consideraciones de dirigentes obreros, periodistas e intelectuales que juzgaban el accionar de los trabajadores tucumanos de acuerdo a un abanico de prejuicios, miedos y descalificaciones y, por esa vía, alimentaban la percepción del trabajador del norte como un sujeto vicioso, ignorante e incapaz de practicar conductas racionales. La segunda, vinculada a las tensiones y enfrentamientos que existían al interior del anarquismo durante el periodo estudiado en distintas ciudades argentinas y que se reflejaba en las impugnaciones de las publicaciones libertarias a los

\footnotetext{
${ }^{51}$ Idem.

${ }^{52}$ Idem.

${ }^{53}$ Idem.
} 
movimientos de protesta que al parecer no se ajustaban a los lineamientos propuestos por ellos. En esa tónica, las mismas características del espacio de actuación de los obreros panaderos en huelga, el Centro Cosmopolita de Trabajadores, ámbito en donde coexistían trabajadores de distintas corrientes ideológicas, desde el reformismo liberal al socialismo y el anarquismo, posiblemente motivó las suspicacias y cuestionamientos de El Obrero y El Obrero Panadero al accionar de los huelguistas tucumanos. ¿Hasta qué punto los consideraban anarquistas a los trabajadores del pan en Tucumán? es una de las preguntas que se desprende del análisis de las fuentes consultadas. Finalmente, una tercera cuestión que me gustaría proponer remite a la misma convivencia -por otra parte no pacífica ni exenta de peleas y rispideces- entre los trabajadores que integraban el Centro Cosmopolita de Trabajadores. ¿No sería posible pensar que esta composición heterogénea del centro cosmopolita constituye un indicador de la debilidad del movimiento obrero en Tucumán en su etapa formativa? La fuerza todavía relativa de los socialistas y anarquistas en la provincia que se observó en estos primeros años se revirtió tiempo después, cuando estas tendencias incrementaron su protagonismo en la escena pública. En el caso concreto del anarquismo su presencia adquiere mayor visibilidad en la década de 1910, en consonancia con la creación y el desarrollo de los Talleres Ferroviarios de Tafí Viejo.

Otra cuestión que se desprende de las demandas laborales anarquistas revisadas en este artículo, como la protesta de los dependientes de comercio en 1912, permite inferir las consideraciones comunes que recorrían los discursos de la época sobre el anarquismo, definido como un movimiento peligroso, violento y perjudicial para los intereses de la sociedad. Desde esta valoración negativa que se reflejaba en numerosas narraciones de la prensa periódica de la época se relataban y juzgaban las prácticas de los trabajadores. En esa línea, una modalidad usual era argumentar la presencia de uno o dos activistas libertarios como los causantes de las protestas que alarmaban a la opinión pública por su grado de virulencia. Restringir el reclamo de los trabajadores al accionar de unos pocos individuos y no reconocer la participación de un grupo mayor de trabajadores evitaba a los grupos dominantes definir al anarquismo como un movimiento con presencia propia entre los trabajadores y sostener la teoría de éste como un movimiento exótico, con poca raigambre entre los trabajadores del país. Es cierto que al formular un diagnóstico sobre la sociedad los anarquistas esgrimían discursos que recogían tópicos universales y en ocasiones alejados de la realidad local, pero esto no significaba que el anarquismo careciera de alcance real en el movimiento obrero argentino, especialmente en la primera década del siglo XX, tal como ya fue sugerentemente demostrado por especialistas sobre el tema en el país, como Juan Suriano.

Sin ánimo de agotar el tema con esta investigación y, por el contrario, con el objetivo de ofrecer algunas breves reflexiones, proporcionar ciertas pistas y mostrar senderos que podrán ser transitados para fortalecer una línea de análisis que considero fructífera, en el trabajo presentamos también una primera reconstrucción del perfil de algunos dirigentes libertarios que actuaron en la provincia durante los años bajo estudio. Recuperar los rostros de militantes como el periodista y peluquero Ángel F. Derisso, así como detenernos en algunos contornos del accionar de Tomás Delgado, dirigente de la Federación Obrera Local, referente de la sociedad de resistencia de mozos y figura sobresaliente del movimiento obrero en Tucumán en su etapa pionera, resultan sugerentes 
en ese sentido. Tal como se desprende del análisis de las fuentes, ambos, recorrieron un itinerario que no limitaba su influencia al caso tucumano y vivieron en la provincia durante un periodo de tiempo. Por otra parte, tanto Tomás Delgado como Ángel Derisso tuvieron una participación protagónica en las publicaciones de la época, en particular, en los órganos de expresión combativos y libertarios. En el caso del primero, las páginas de Germinal fueron el foro en el cual desplegó su pensamiento en torno a temas tales como la organización gremial, las luchas y las conmemoraciones obreras. En particular la efeméride del Primero de Mayo fue objeto de varios artículos destinados fundamentalmente a diferenciar la postura del anarquismo de las concepciones del socialismo, tendencia que dominó esta efeméride nodal del movimiento obrero.

De acuerdo con lo que conocemos sobre Tomás Delgado es factible sugerir que éste trazó una línea de separación entre él y el movimiento obrero provincial. Al dirigirse a los trabajadores de Tucumán estableció una demarcación que situaba los atributos positivos del lado del dirigente obrero y ubicaba las conductas y hábitos negativos del lado de los trabajadores de la provincia. Por un lado, tiene sentido suponer que su mirada recogía los prejuicios y descalificaciones que pesaban sobre los trabajadores del Norte argentino y que se expresaban en la prensa partidaria y en los diarios gremiales obreros. También es factible pensar que su crítica a los militantes locales respondía al enojo, la decepción y la queja por las conductas de los trabajadores que se mostraban demasiado interesados en exaltar a las figuras y caían frecuentemente en personalismos, tal como en algún momento denunció en sus artículos en Germinal Tomás Delgado. En todo caso, queda abierta la cuestión acerca del impacto de las distintas posiciones al interior del anarquismo, entendido como un movimiento no unívoco, en los dirigentes obreros que juzgaban las expresiones de los militantes tucumanos.

No quiero cerrar este trabajo sin antes recuperar algunas preguntas que planteamos al comienzo. Con ese fin, considero oportuno apuntar que los dirigentes libertarios que actuaron en Tucumán al despuntar el siglo XX provenían de otras latitudes geográficas, llegaban a la provincia como parte de sus itinerarios de militancia y propaganda obrera y eventualmente interactuaban con los militantes locales desde una mirada prejuiciosa y descalificadora sobre sus conductas. Por otra parte, según lo examinado en las fuentes, es factible proponer que los espacios de actuación de los anarquistas en la provincia fueron los gremios, las sociedades de resistencia, los centros obreros y las federaciones. Respecto a los medios de expresión de los activistas libertarios interesa destacar el valor asignado a las conferencias, las veladas literario musicales, las revistas y los periódicos dirigidos a concientizar a los trabajadores en la importancia de la lucha obrera, el combate a la sociedad capitalista y la construcción de una sociedad más justa e igualitaria. Ello implicaba recordar sucesos claves de la gesta obrera, como el Primero de Mayo, entendido como un día de protesta y de duelo e incentivar la lucha obrera destinada a obtener mejores condiciones de trabajo a través de mayores salarios y una jornada menos extensa. Precisamente estas consignas orientadas a promover una transformación social y edificar un orden social más libre y justo, combinadas con muestras de solidaridad obrera y el combate a otras tendencias de izquierda como el socialismo, incentivaron a los anarquistas a movilizarse e intervenir en la escena pública al despuntar el siglo XX. De sus anhelos, recorridos y límites aún queda mucho por decir, pero esto será ya materia de otro trabajo.

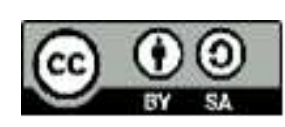




\section{Bibliografía}

- Aizpuru, Mikel y Rivera, Antonio. Manual de historia social del trabajo, Madrid: Siglo XXI, 1994.

- Bilbao, Santiago. "Anarquismo en el noroeste a principio del siglo XX: Germinal, publicación tucumana", Estudios del Trabajo, N ${ }^{\circ} 28,2004,143-151$.

- Bilhão, Isabel. "Dia de festa, dia de luto ou feriado nacional? As diferentes concepções do Primero de Maio no Brasil ao longo dos anos 1929", Hib, Revista de Hitoria Iberoamericana, Vol. 6, nº 1 , 2013, 29-52.

- Bravo, María Celia. "Liberales, socialistas e Iglesia frente a la situación de los trabajadores en Tucumán", Suriano, Juan, La cuestión social en la Argentina, 1870-1943, Buenos Aires: La Colmena, 2000, 31-61.

- Bravo, María Celia. Campesinos, azúcar y política. Cañeros, acción corporativa y vida política en Tucumán (1895-1930), Rosario: Prohistoria, 2008.

- Bravo, María Celia y Teitelbaum, Vanesa. "Socialistas y católicos disputando el mundo los trabajadores. Protesta, sociabilidad y política en Tucumán (1895-1910)", Entrepasados, Revista de Historia, Año XVIII, nº 35, Buenos Aires, 2009, 67-87.

- Breves Contribuciones del Instituto de Estudios Geográficos, Monografía I, Tucumán, Universidad Nacional de Tucumán, Facultad de Filosofía y Letras, 1988.

- Camarero, Hernán. A la conquista de la clase obrera. Los comunistas y el mundo del trabajo en la Argentina, 1920-1935, Buenos Aires: Siglo XXI, 2007.

- Campi, Daniel. Azúcar y trabajo. Coacción y mercado laboral, Tucumán, 1856-1896, tesis doctoral (inédita), Universidad Complutense de Madrid, 2002.

- Curia de Villeco María Elena y Bolognini, Víctor Hugo. Inmigración en Tucumán, Tucumán: Universidad Nacional de Tucumán, 1992.

- Di Stefano, Roberto. Capítulo Uno/ 1776-1860, Luna, Elba y Cecconi, Elida, (Idea y coordinación), De las cofradías a las organizaciones de la sociedad civil". Historia de la iniciativa asociativa en Argentina, 1776-1990, Buenos Aires: Edilab Editora, 2002, 23-97

- Falcón, Ricardo. Los orígenes del movimiento obrero (1857-1899), Buenos Aires: Centro Editor de América Latina, 1984.

- Falcón, Ricardo. El mundo del trabajo urbano, 1890-1914, Buenos Aires: Centro Editor de América Latina, 1986.

- Falcón, Ricardo, La Barcelona Argentina, Rosario: Laborde, 2005.

- Fernández, María Estela. "Salud y condiciones de vida. Iniciativas estatales y privadas, Tucumán fines del siglo XIX y comienzos del XX", Adriana Álvarez, Irene Molinari y Daniel Reynoso (editores). Historia de enfermedades, salud y medicina en la Argentina de los siglos XIX y XX, Mar del Plata: Universidad Nacional de Mar del Plata, 2004.

- Fernández, María Estela. "Las políticas de salud: el caso de los hospitales en Tucumán a fines del siglo XIX", X Jornadas Interescuelas/Departamentos de Historia, Rosario, 2005. 
- García Soriano, Manuel, "El periodismo tucumano: 1817-1900. Ensayo de investigación sobre un aspecto de la cultura de Tucumán durante el siglo XIX", Cuadernos de Humanitas, 38, Tucumán: Universidad Nacional de Tucumán, 1972.

- Grez Toso, Sergio. "La trayectoria histórica del mutualismo en Chile (1853-1990). Apuntes para su estudio", Mapocho, № 35, 1994, 293-315.

- Kocka, Jürgen. "Los artesanos, los trabajadores y el Estado: hacia una historia social de los comienzos del movimiento obrero alemán," Historia Social, № 12, 1992, 101-11.

- Larraza Micheltorena, María del Mar. "El asociacionismo obrero pamplonés (1900-1923)", Gerónimo de Uztariz, N 14/15, 1999, 55-104.

- Lida, Clara E. y Yanquelevich, Pablo. "Presentación", Lida, Clara E. y Yanquelevich, Pablo, (compiladores), Cultura y política del anarquismo en España e Iberoamérica, México: El Colegio de México, 2012, 9-25.

- Lobato, Mirta Zaida. La prensa obrera, Buenos Aires: Edhasa, 2009.

- Lobato, Mirta Zaida y Palermo, Silvana Alejandra. "Del trabajo a las calles: dignidad, respeto y derechos para los y las trabajadoras", Mirta Zaida Lobato (Editora). Buenos Aires. Manifestaciones, fiestas y rituales en el siglo XX, Buenos Aires: Biblos, 2011, 45-74.

- Mases, Enrique. "El tiempo libre de los trabajadores en la norpatagonia. De la cultura política, las prácticas recreativas y deportivas al disciplinamiento social 1900-1945", Quinto Sol, N 9-10, 2005-2006, 73-97.

- Moreno, Daniela y Chiarello, Analía. "La ciudad de papel. Los proyectos de avenida dentro del casco fundacional", Perilli de Colombres Garmendia, Elena y Romero, Estela. La Generación del Centenario y su proyección en el noroeste argentino (1900-1950), Tucumán: Centro Cultural Alberto Rougés, 2006.

- Paterlini de Koch, Olga. Pueblos Azucareros de Tucumán, Tucumán, Universidad Nacional de Tucumán, 1987.

- Poy, Lucas. "Socialismo y anarquismo en los orígenes del Primero de Mayo en Argentina (18901895), Trabajadores, Año 1, N² 2, 2011, 27-57.

- Poy, Lucas. Los orígenes de la clase obrera argentina. Huelgas, sociedades de resistencia y militancia política en Buenos Aires, 1888-1896, Buenos Aires, Imago Mundi, 2014.

- Sabato, Hilda. Capítulo 2/1860-1920. "Estado y sociedad civil”, Luna y Cecconi, op. cit, 99-167.

- Saltor, Irene. "Aspectos de la Modernidad. Tucumán, 1880-1890", Revista de la Junta de Estudios Históricos de Tucumán, Año VIII, N 5, 1993, 33-61.

- Suriano, Juan, Anarquistas. Cultura y política libertaria en Buenos Aires, 1890-1910, Ediciones Manantial, Buenos Aires, 2001.

- Suriano, Juan. "El largo camino hacia la ciudadanía social", Torrado, Susana (comp.). Población y bienestar en la Argentina del primero al segundo Centenario. Una historia social del siglo XX, 2007, 67-95.

- Suriano, Juan, "Las prácticas culturales del anarquismo argentino", Lida y Yanquelevich. op. cit., 145-74.

- Suriano, Juan y Anapios, Luciana, "Anarquistas en las calles de Buenos Aires (1890-1930)", Lobato, 2011, op. cit., 84 -85.

- Tarcus, Horacio, Diccionario biográfico de la izquierda argentina. De los anarquistas a la nueva izquierda (1870-1976), Buenos Aires, Emecé Editores, 2007.

- Viguera, Aníbal, "El primero de mayo en Buenos Aires, 1890-1950: evolución y usos de una tradición", Boletín del Instituto de Historia Argentina y Americana "Dr. E. Ravignani", Tercera Serie, n. ${ }^{\circ} 3,1991,57-60$.

\section{Publicaciones periódicas}


Vanesa Teitelbaum, El anarquismo en Tucumán: expresiones de protesta y rituales obreros, 1900-1912, Izquierdas, 28:27-92, Julio 2016

\author{
El Obrero \\ El Orden \\ El Obrero Panadero \\ Germinal \\ La Acción Socialista \\ La Gaceta \\ La Protesta \\ La Vanguardia
}

